${ }^{1}$ Institute of Archaeology and Ethnology

Polish Academy of Sciences

Wrockaw

slawomir.mozdzioch@gmail.com

ORCID: 0000-0001-9228-3439

${ }^{2}$ University of Opole

Opole

ewa.mozdzioch@gmail.com

ORCID: 0000-0001-5220-0205

SŁAWOMIR MOŹDZIOCH ${ }^{1}$, EWA MOŹDZIOCH ${ }^{2}$ ANNAMARIA SAMMITO, PIETRO MILITELLO

\title{
Castello dei Tre Cantoni in Scicli in the light of new excavations.
} First observations

Abstract. In connection with a research programme concerning the role of the Normans in the formation of the cultural face of medieval Europe, the Research Centre for Late Antique and Early Medieval Studies of the Institute of Archaeology and Ethnology Polish Academy of Sciences in Wrocław began excavations in Scicli based on a scientific cooperation agreement with Soprintendenza per i Beni Culturali ed Ambientali di Ragusa with the support of local volunteers. The project concerned the castle, known as Castello dei Tre Cantoni (also Castelluccio), occupying the top of the hill of S. Matteo above the town of Scicli (Fig. 1). The time of construction of both castles and their functioning period remains a subject of inquiry for archaeologists, historians, and architectural historians. The research carried out in 2018 produced the first information, documented by systematic excavations, on the chronology of the fortification on the hill of San Matteo. Thanks to them, it was possible to discover a building workshop dating from the second half of the $14^{\text {th }}$ to the first half of the $15^{\text {th }}$ century and confirm the castle wall's construction (reconstruction?) at the same time. Both the stratigraphy and the ${ }^{14} \mathrm{C}$ dates were obtained to confirm the castle's functioning from the $2^{\text {nd }}$ half of the $14^{\text {th }}$ century.

Keywords: medieval Sicily, castle, Scicli, Castello dei Tre Cantoni, medieval archaeology, lime kiln, non-invasive research. 
${ }^{1}$ Institute of Archaeology and Ethnology

Polish Academy of Sciences

Wrockaw

slawomir.mozdzioch@gmail.com

ORCID: 0000-0001-9228-3439

${ }^{2}$ University of Opole

Opole

ewa.mozdzioch@gmail.com

ORCID: 0000-0001-5220-0205

SŁAWOMIR MOŹDZIOCH ${ }^{1}$, EWA MOŹDZIOCH ${ }^{2}$ ANNAMARIA SAMMITO, PIETRO MILITELLO

\section{Castello dei Tre Cantoni in Scicli in the light of new excavations.}

First observations

Abstract. In connection with a research programme concerning the role of the Normans in the formation of the cultural face of medieval Europe, the Research Centre for Late Antique and Early Medieval Studies of the Institute of Archaeology and Ethnology Polish Academy of Sciences in Wrocław began excavations in Scicli based on a scientific cooperation agreement with Soprintendenza per i Beni Culturali ed Ambientali di Ragusa with the support of local volunteers. The project concerned the castle, known as Castello dei Tre Cantoni (also Castelluccio), occupying the top of the hill of S. Matteo above the town of Scicli (Fig. 1). The time of construction of both castles and their functioning period remains a subject of inquiry for archaeologists, historians, and architectural historians. The research carried out in 2018 produced the first information, documented by systematic excavations, on the chronology of the fortification on the hill of San Matteo. Thanks to them, it was possible to discover a building workshop dating from the second half of the $14^{\text {th }}$ to the first half of the $15^{\text {th }}$ century and confirm the castle wall's construction (reconstruction?) at the same time. Both the stratigraphy and the ${ }^{14} \mathrm{C}$ dates were obtained to confirm the castle's functioning from the $2^{\text {nd }}$ half of the $14^{\text {th }}$ century.

Keywords: medieval Sicily, castle, Scicli, Castello dei Tre Cantoni, medieval archaeology, lime kiln, non-invasive research. 
In connection with a research programme concerning the role of the Normans in forming the cultural face of medieval Europe, the Research Centre for Late Antique and Early Medieval Studies of the Institute of Archaeology and Ethnology Polish Academy of Sciences in Wrocław began excavations in Scicli based on a scientific cooperation agreement with Soprintendenza per i Beni Culturali ed Ambientali di Ragusa, with the support of local volunteers ${ }^{1}$.

The project concerned the castle, known as Castello dei Tre Cantoni (also Castelluccio), occupying the top of the hill of San Matteo above the town of Scicli (Fig. 1). The hill has the form of a plateau with cliff slopes typical of the limestone landscape of the Ragusa area. A small castle, Castellaccio, situated on the hill's northern edge, is also part of the defensive complex (Fig. 2). Likely, both castles were formerly one defensive complex, of which Castello dei Tre Cantoni (Castelluccio) was the main element. It was this that was the subject of excavations in 2018 (Fig. 3).

The time of construction of both castles and the period in which they functioned remain a subject of inquiry for archaeologists, historians and architectural historians (Militello 1989; Canzonieri 1997; Di Stefano, Fiorilla 1997; Di Stefano 2008). The remains of the walls and information contained in the written sources put their defensive function beyond question, whereas it is far more difficult to reconstruct the functions performed by these castles in a local and regional context.

Formal analyses of the architecture of Castelluccio Castle, as well as archaeological finds collected from the surface and obtained through small-scale surveys, do not exclude, according to both architects (Canzonieri 1997, p. 59) and archaeologists (Militello 1989; 2008, p. 325; Di Stefano, Fiorilla 1997, p. 94; Di Stefano 2008, p. 37), that the first walls were built already in the Byzantine period.

Based on an analysis of the technique of construction of the walls, Canzonieri distinguished phase I, related to the period of Byzantine rule and falling in the $8^{\text {th }}$ century, but at the same time pointed out the absence of Byzantine artefacts stratigraphically linked to the walls (Canzonieri 1997, p. 59). Unfortunately, apart from Byzantine coins from private collections, no finds confirming this chronology have been obtained from the site (Di Stefano, Fiorilla 1997).

However, this did not prevent the scientific literature from referring to the functioning of a Byzantine castle at Scicli (Santagati 2012, p. 235). In this context, it is worth noting that in 2018, among the ceramic material from trenches 3 and 4, a dozen pottery fragments that may date from the Byzantine period were encountered.

So far, no extensive archaeological work has been carried out at this site. The first small-scale excavations were carried out in 1991, limited to a few

${ }^{1}$ We would like to express our thanks to the initiators, organisers and co-leaders of the archaeological research,the Soprintendenza BBCCAA Ragusa, with its director, dr. Antonino De Marco, Doctor Salvina Fiorilla, and the volunteers, the inhabitants of Scicli under the leadership of Doctor Bartolo Millili. 


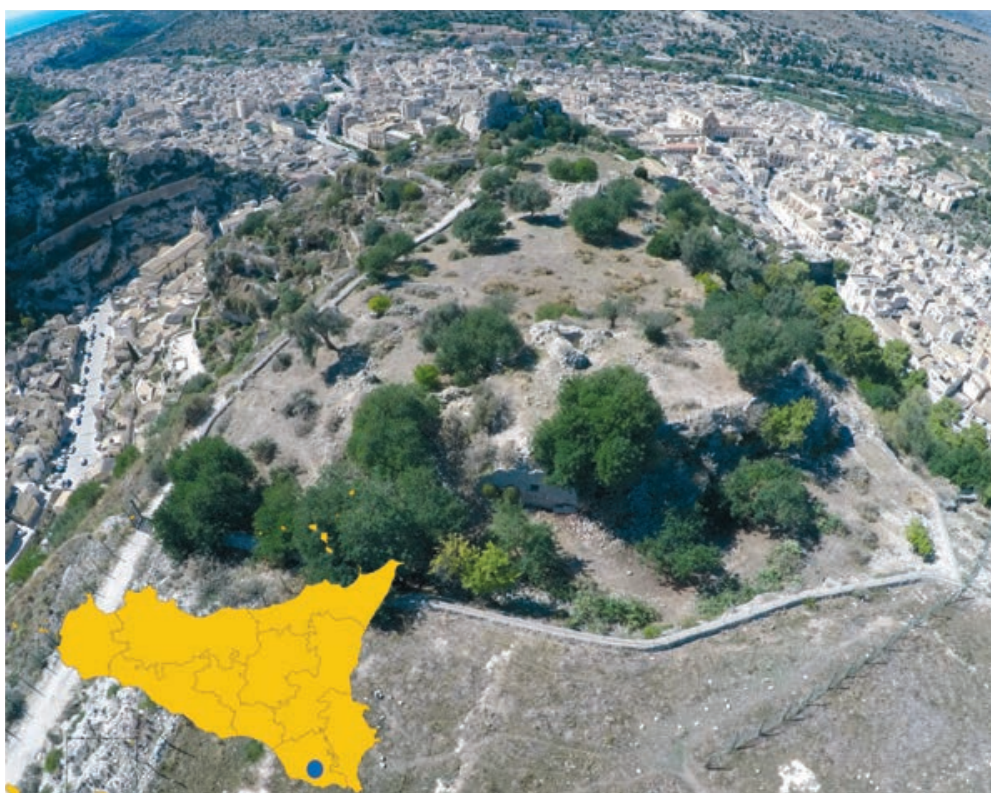

Fig. 1. Location of the site. View of the San Matteo hill from the south-east. In the foreground, the ruins of the castle Castello Dei Tre Cantoni and the remains of the characteristic triangular tower (photo by P. Wroniecki)

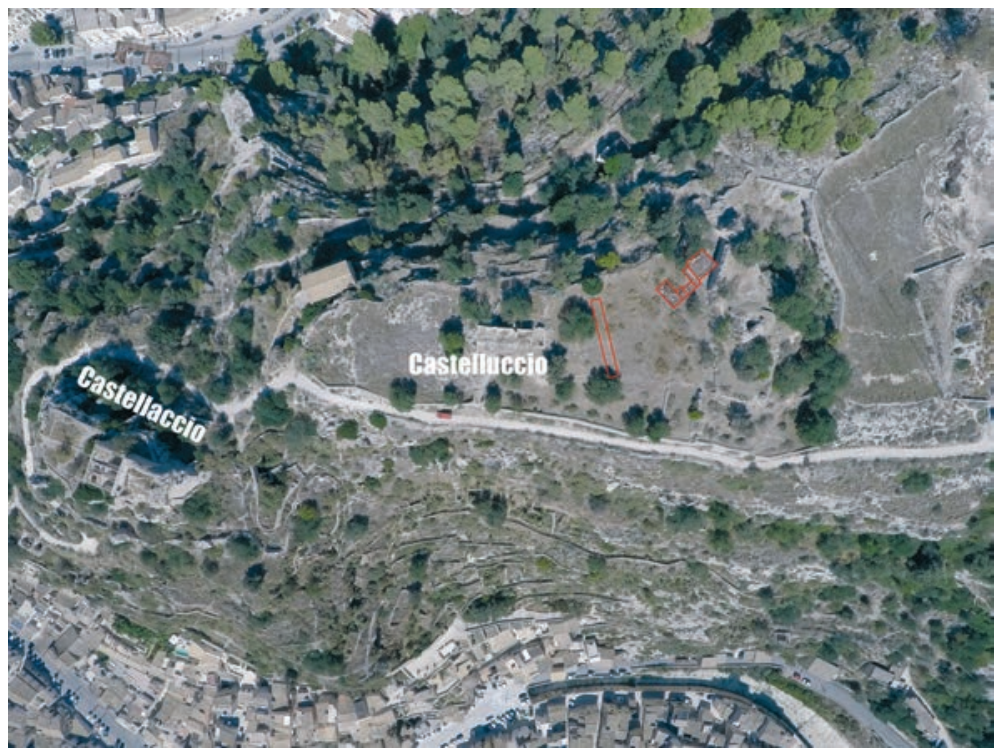

Fig. 2. View of the hill of San Matteo with both castles and trenches (photo by P. Wroniecki) 
small-scale soundages, which led to the conclusion that the oldest phase of the castle walls could be dated to the $12^{\text {th }}$ century (Di Stefano, Fiorilla 1997).

From the point of view of the above-mentioned research programme, it would be important to confirm a Norman phase during the functioning period of the larger castle (Castelluccio) and verify the claims appearing in the literature about the Norman origins of the smaller castle (Castellaccio). The probability of the discovery of this phase is increased by the fact that during the excavations carried out in 2018 at the Castelluccio site, in addition to late-medieval and modern ceramics, numerous fragments of $11^{\text {th }}$ - to $12^{\text {th }}$-century pottery and a bronze coin of William II (1166-1189) were found.

During the 1991 survey, the oldest ceramic artefacts were dated to the $12^{\text {th }}$ century (Di Stefano, Fiorilla 1997, p. 95). The analysis of the ceramics discovered in 1991 and 2018 was carried out by the experienced researcher of Sicilian medieval ceramics, Doctor Salvina Fiorilla².

The castle's characteristic triangular tower offered some hope in dating based on formal analysis of the architecture (Militello 1989). Unfortunately, however, it has few analogues. Similar triangular towers known from southern Italy and Sicily have been dated to the younger phases of the Middle Ages (Montegualtieri tower - Fig. 4, Sutrium tower in Abruzzo, Castello di Santa Lucia del Mela in Sicily). Their presumed chronology has not yet been confirmed by systematic archaeological research.

In 2018, it was possible to subject several samples of organic remains from mortar and charcoal to ${ }^{14} \mathrm{C}$ analysis, obtaining dates from periods more-or-less within the $2^{\text {nd }}$ half of the $14^{\text {th }}$ century (the building workshop) and the $1^{\text {st }}$ half of the $15^{\text {th }}$ century (the face of the castle wall).

Establishing the chronology of the site will allow us to carry out the next research task, which is to determine the nature of the changes in the functions performed by Castello dei Tre Cantoni over the centuries, until the earthquake of 1693 , which put an end to its existence.

The first reference to a defensive site at Scicli comes from 1255 when a letter from Pope Alexander IV mentions the castrum Sicli belonging to Syracuse's Diocese (Militello 1989, p. 22).

Scicli as terra, castrum - settlement (administrative area) - appears in Latin documents already earlier, first in the bull of Pope Urban II of 1093, then in the bull of Alexander III of 1169 (Pirri 1733, pp. 618, 622). The church of St Lawrence in Scicli, known from the bull of 1169, was also mentioned in the document of Emperor Henry VI of 30 December 1194, confirming the Sicilian possessions of the Jerusalem abbey of St Mary Latin. The Modica area, including Scicli, went

${ }^{2}$ We would like to thank Doctor Salvina Fiorilla for valuable cooperation in the analysis of the pottery collected during the excavations. 


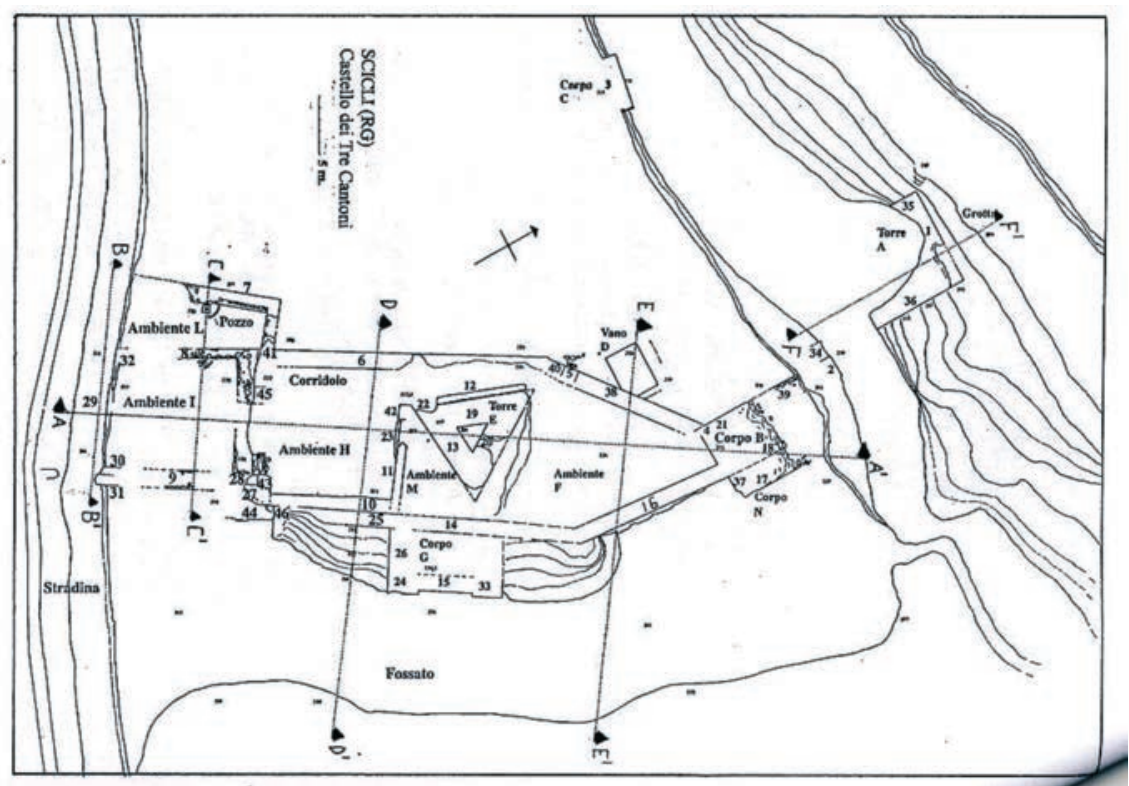

Fig. 3. Castello dei Tre Cantoni. Plan of the remains of the main section of the castle (after Canzonieri 1997)

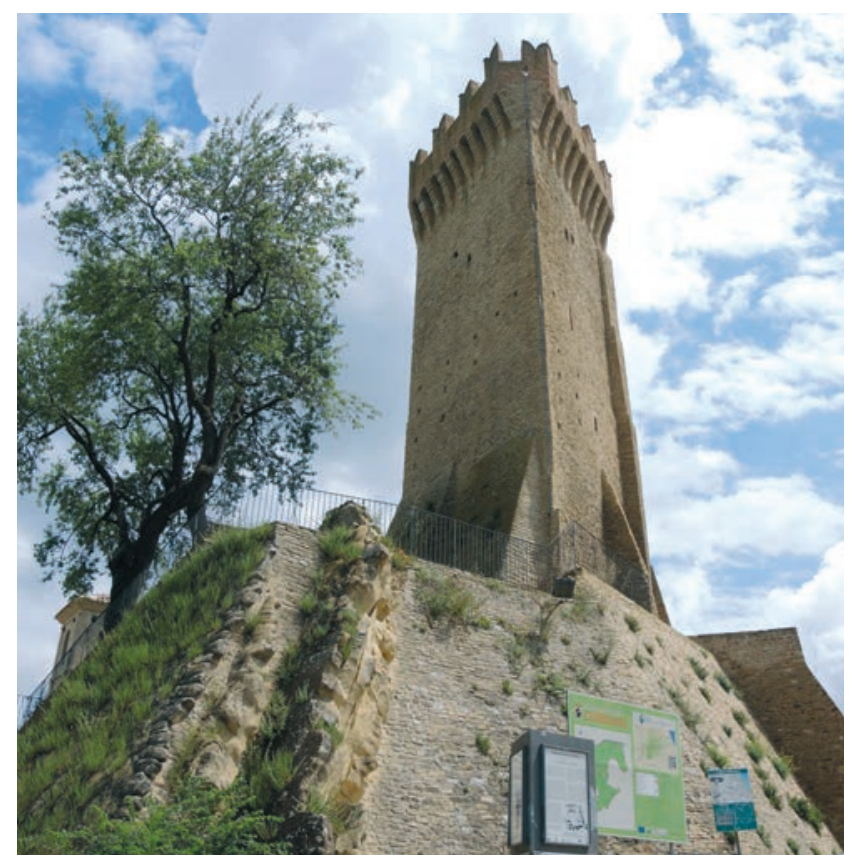

Fig. 4. The triangular tower of Montegualtieri in Abruzzo (after https://commons. wikimedia.org/wiki/File:Torre_di_Montegualtieri_01.jpg) 
through various fates and its administrators changed with the changing elites ruling Sicily.

On September 13, 1255, Pope Alexander IV entrusted as a fief to the 'nobleman' Rogerio Finecte (Ruggero Fimetta) de Lentino some castles in the Diocese of Syracuse including: '[...] Bizini, Modice, Sicli et Palatioli castra Siracusane diocesis' (Monumenta, 1894, p. 370). In 1282, after the Sicilian Vespers, King Peter III of Aragon granted the county of Modica to Frederick Mosca, who was at the head of the anti-Andegavian revolt in Modica and Scicli. The new count sided with James II of Aragon against his younger brother Frederick, whom the Sicilian parliament elected in 1296 as the island's new ruler. This, already as King Frederick II (III) of Aragon, took the county from the Mosca family and gave it to Manfred I Chiaramonte. However, it remained in the family in its own way, as Chiaramonte was the husband of Isabella, daughter of Frederick Mosca. The Chiaramonte family, one of the wealthiest Sicilian families, ruled the county until 1392, when it passed into the Spanish Cabrera family's hands (Sipione 1968, p. 128). It remained in Spanish families' hands until the abolition of feudalism in Sicily's kingdom in 1812.

The castles on the San Matteo hill are mentioned in a document of 7 November 1346, which refers to a castrum magnum and a castrum parvum (Sipione 1968, pp. 222-224; Canzonieri 1997, p. 65). In March 1361, Muzio Barba, castellan of Scicli on behalf of the King of Naples, gave the castle to Artale Alagona, a supporter of King Frederick III (IV) (Michele da Piazza, 1980, p. 390). The documents preserved in Modica's archives inform us about the castle and its equipment from the $16^{\text {th }}$ century onwards. We learn about the armament, for example, from a notarial deed issued in 1532 (Cataudella 1988, pp. 81-82).

In 1535, ten military garrisons called sergenzie were established in Sicily, one of which (IV) was in Scicli. The reform of the island's defence system contributed to the castle's loss of importance in favour of a garrison quartered in the city. In the first half of the $16^{\text {th }}$ century, the castle's garrison consisted of four soldiers commanded by a castellan. The preserved archival documents provide copious information about the castle's renovations in the $16^{\text {th }}$ and $17^{\text {th }}$ centuries (for a summary; Canzonieri 1997, pp. 61-75), attesting, among other things, to the functioning of a prison in the castle. Subsequent repairs and renovations did not strengthen its structure enough to withstand the earthquake of 1693.

Just as in the case of Piast Poland, the excavations from the second half of the $20^{\text {th }}$ century have given archaeologists a good basis to contribute to the discussion on the role of the castle organisation in the first Early medieval states (Moździoch 2002; 2004); similarly, the studies on medieval centres of power in Sicily (Baranowski et al. 2017; Vassallo, Moździoch 2018; Krąpiec et al. 2020) and studies on the sociotopography of medieval castles, including the castle of Scicli, can contribute new data to the discussion of the origins and role of Sicilian castles between the $11^{\text {th }}$ and $15^{\text {th }}$ centuries - a process referred t o in Italian literature as 
incastellamento (Giuffre 1980; Bresc 1984; 1994; Maurici 1992; 1998; Lesnes 1997; Bresc, Maurici 2009; Augenti, Galetti 2018).

It remains debatable whether and to what extent there was continuity between the network of defensive sites of Late Antiquity and the Middle Ages (Arcifa 2000). Most likely, however, as in the Poland of the Piasts, most of the defensive sites centres of power created by the rulers of the emerging Norman state in Sicily - were built on undeveloped land (in cruda radice), which was justified both symbolically and economically (Bresc, Maurici 2009, p. 273). The exceptions were strongholds built within urban agglomerations, which had existed and functioned since Antiquity, but even there, their location had to ensure a secure separation from the city inhabitants and good defensive conditions.

Unlike the Byzantine and Arab periods, the Norman period's castles mainly served the state's fiscal organisation (Maurici 1992) and thus more for control than for the protection of the local population.

The number of castles in Sicily whose remains have survived to the present day was, according to the catalogues of the Palermo Conservation Office in 2001, about 294. According to Luigi Santagati, there are more than 350 of them. Many are the remains of medieval castles, among which a small number are Byzantine or Arab fortifications (Santagati 2006, p. 39).

Abandoned after the earthquake of 1693, the castles of eastern Sicily have been little studied archaeologically. Younger structures, dating to the $16^{\text {th }}$ and $17^{\text {th }}$ centuries, have obliterated traces of medieval phases, and the complexity of the sites, resulting from the multiplicity of cultural stratifications, makes interpretation difficult.

The study of the material culture of the so-called Norman period (eta normanna) in Sicily has developed only in recent years, being overshadowed by research on Antiquity. The example of the research at Piazza Armerina, where the focus mainly on the study of remains from the Late Roman period has resulted in the neglect of the documentation of stratifications from the medieval period (Pensabene 2008, p. 13), is not an exceptional case.

Alessandra Molinari's critical remarks on the state of medieval research in Sicily, despite a significant increase in the number of sources and publications in recent years, remain valid (Molinari 2004). In a similar vein, Lucia Arcifa also comments mainly on the Byzantine and Arab periods (Arcifa 2010, p. 105). Despite the scarcity of source publications, much archaeological work has been devoted to pottery, due to the mass occurrence of this type of artefacts and their still-great importance as a determinant of chronology.

The recently developed database of medieval ceramic finds from Sicily best illustrates the still-urgent need to publish this type of source (Mangiaracina 2012, p. 52, Fig. 1). The basis for inferring cultural contacts and the chronology of sites is still primarily the formal-typological analysis of ceramics. In the absence 
of well-documented stratigraphic systems and the publication of complete assemblages of finds that could be used for comparative purposes, conclusions resulting from this analysis are often difficult to verify, as they are illustrated by single, randomly selected analogues. Consequently, the basic argument for their validity remains the authority and experience of the researcher.

The process of archaeological identification of early- and late-medieval settlements in Sicily is still poorly advanced ${ }^{3}$. This topic was also raised in the works of Lucia Arcifa, Giuseppe Cacciaguerra and Patrizio Pensabene (Arcifa, Tomasello 2005; Cacciaguerra 2009; Pensabene 2006). In the above-mentioned works, however, special attention is paid to Late Antiquity and the Early Middle Ages, including the Byzantine period, and the authors are generally interested in selected microregions. The settlement network of the Norman period is still poorly recognised archaeologically.

A similar situation exists in the region of central southern Sicily (Di Stefano, Fiorilla 2003, p. 510). Settlement studies on the Hyblean (Iblea) territory have mainly concerned eras older than the Middle Ages (Di Stefano 2003; 2008; Militello 2008). The region itself was the subject of research by Paolo Orsi in the late $19^{\text {th }}$ century. From the early $20^{\text {th }}$ century, his work was joined by Salvatore Minardo. In the $20^{\text {th }}$ century, research work gained a great dynamic, and undoubtedly Giuseppe Agnello, Giovanni Di Stefano, Aldo Messina, Vittorio G. Rizzone and Anna Maria Sammito played an important role in the archaeological research of the region. Archaeological research was mainly focused on surface exploration, with few stationary excavations. This is undoubtedly one reason for the difficulty in reconstructing the history of settlement in the area.

However, the settlement network of the region during the Arab and Norman periods, reconstructed mainly based on toponymy and written sources, has been presented in recent years (Fiorilla 2004; 2013).

The establishment of castles during the Norman period caused, over time, a process of settlements that had previously been dispersed being concentrated around new centres of power (this was also the case in the Piast state). The process of settlement concentration in the Norman period was also observed in central southern Sicily (Di Stefano, Fiorilla 2003, p. 513).

The crucial moments in the development of the network of Sicilian castles, which were also accompanied by significant changes in their functions, were the $14^{\text {th }}$ century, i.e. the period of the decline of central power and the rise of the power of the local feudals, and then the $16^{\text {th }}$ century, when a network of districts (sergenzie) was created to ensure the effective defence of the territory of the island against invasions from the sea (Cataudela 1988, p. 81; Carioti 1994, p. 191; Lesnes 1997).

\footnotetext{
${ }^{3}$ On settlement transformations in medieval Sicily - e.g. Bresc 1976; Pesez 1984; Molinari 1994; 2004; 2010a; Fiorilla 2004; 2013; Rizzo 2004; Arcifa, Tomasello 2005; Pensabene 2006; 2008; Cacciaguerra 2009.
} 
The network of castles was later supplemented by several hundred defensive towers, including about 200 situated on the Sicilian coasts.

We do not know whether the above-mentioned important moments in the history of Sicilian castles are reflected in the material culture of the castle of Scicli. Excavations will provide new information in this regard.

The research that started in 2018 at Scicli is a complement to, and consequence of, the excavations carried out by the Institute of Archaeology and Ethnology of the Polish Academy of Sciences in the last six years at Altavilla Milicia near Palermo, where another type of power centre of the time - the monastery of Santa Maria di Campogrosso - was the object of analysis (Krąpiec et al. 2020).

The first step in documenting the archaeological site at Scicli was a topographic survey using GPS RTK. More than 500 measurements were made, from which a DEM was developed and processed into hypsometric and contour maps. Measurements of control points for aerial photogrammetry and measurements of surface architectural features were also made. The area was documented using aerial photographs.

The aerial documentation aimed to create a measurable base map for data presentation, documenting the archaeological site's state and digitising the architectural remains visible on the surface. Two overflights were carried out on two subsequent days in different lighting conditions. During each flight, around 150 images were taken. These were subsequently processed with photogrammetric software to create orthophotomaps.

The small-scale gradiometry survey aimed to test the method in the specific conditions of Scicli. An area of the castle was surveyed with a $1 \times 0.25-\mathrm{m}$ sampling interval. The area chosen for the survey had to be specifically prepared, as low-lying vegetation had to be removed. The research showed that the magnetic gradiometry method could discover subsurface archaeological features, revealing rectilinear structures attributed to previously unknown wall remains.

The castle's area and its immediate surroundings were surveyed using noninvasive methods, including GPR, magnetic and electrical resistivity (Fig. 5). As a result of the non-invasive work, several areas were identified where objects connected with the castle's functioning and immediate surroundings could be expected (Fig. 6).

These included: a) a linear structure, most probably a stone construction running along a grid line from point $\mathrm{A} 1$ to $\mathrm{A} 3$, and b) a circular shadowing visible in a square to the east of lines C1-C2.

To determine these structures' nature, trenches were established: trench 1 along the linear structure and trenches 2-6 cutting through the circular structure and exposing its immediate surroundings (Fig. 7).

Trench 2, to the east of trench 3, was designed to clean the masonry structure examined in 1991 and to excavate cultural layers unexplored at that time (Figs. 8, 9). 


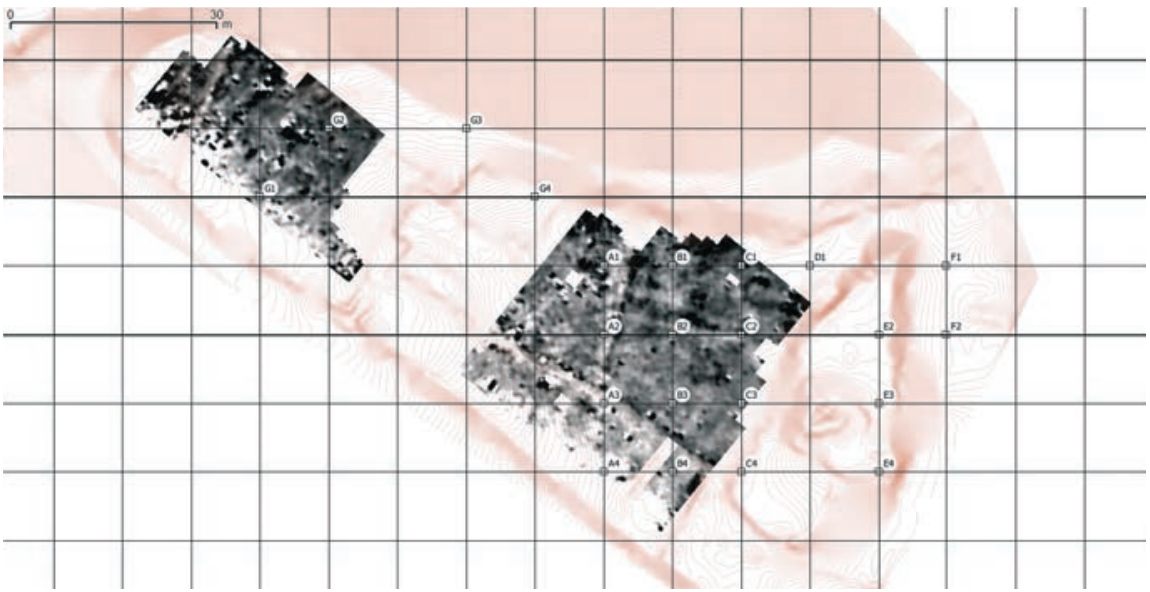

Fig. 5. Results of the geomagnetic survey of the castle site (edited by P. Wroniecki)

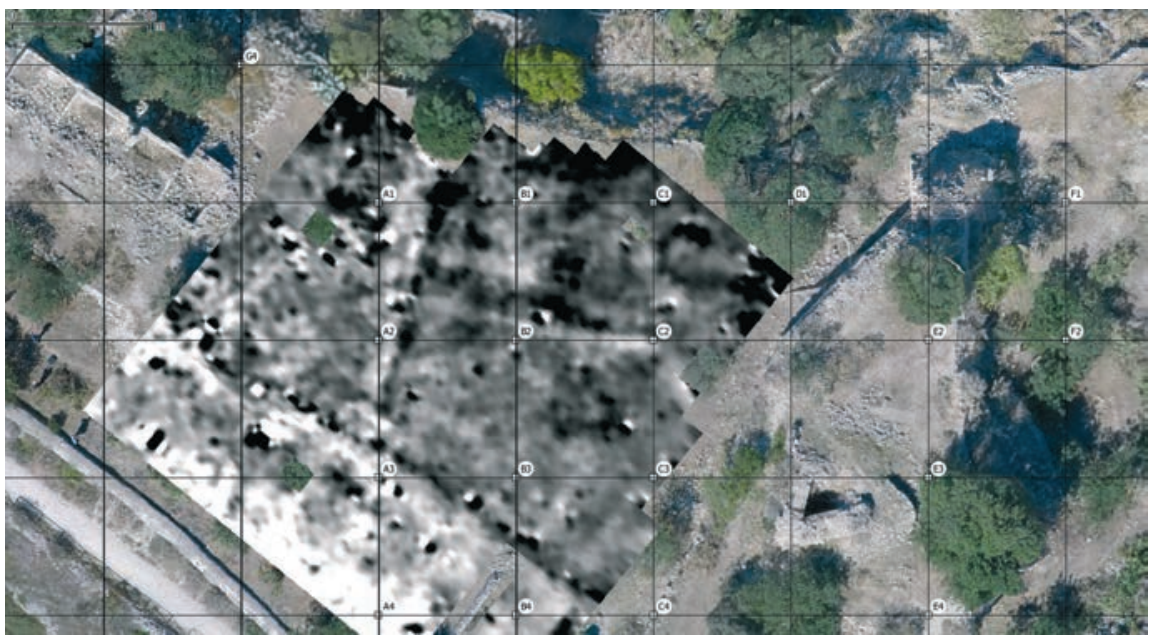

Fig. 6. Castello dei Tre Cantoni. Results of non-invasive research of the castle. Linear structures and circular shading in square C1C2D1D2 are visible (edited by P. Wroniecki)

Trench 1 revealed a wall's remains in the form of a row of large stones forming an even line of over $50 \mathrm{~cm}$ wide towards the west. The wall was explored to a depth of approximately $40 \mathrm{~cm}$, reaching the bedrock (Fig. 10). It has not yet been possible to determine this wall's width, as it was once almost demolished. For the same reason, it is difficult to determine its chronology more precisely. Numerous fragments of pottery, several iron objects and other movable relics were discovered. A characteristic feature of the pottery recovered from this excavation was the presence of Arabic pottery fragments (Fig. 11). 


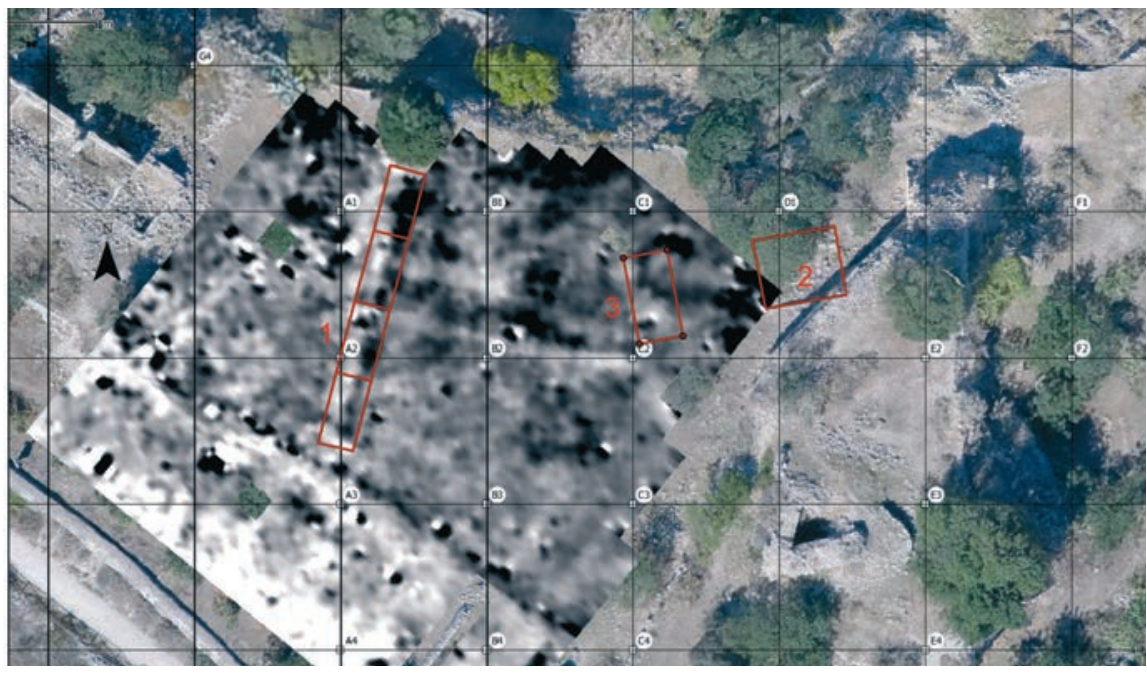

Fig. 7. Castello dei Tre Cantoni. Distribution of trenches 1-3 in the castle area (drawn by K. Chrzan)

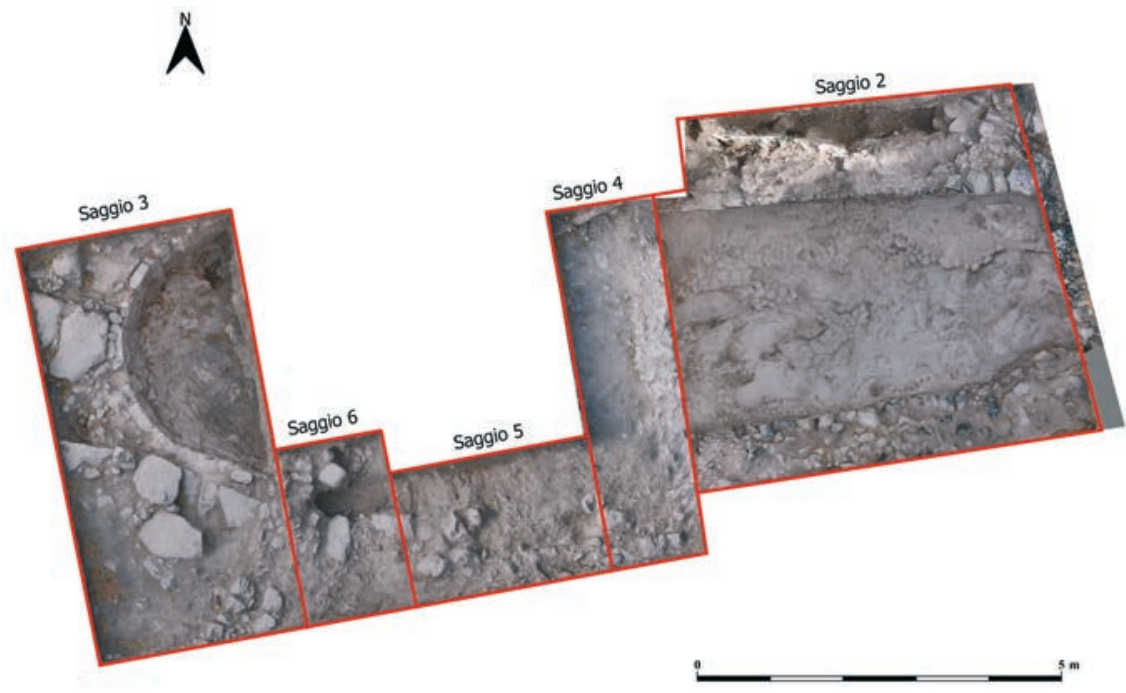

Fig. 8. Plan of excavations in the area of the lime kiln (edited by. K. Chrzan)

In the trenches near the castle wall (2-6), Byzantine and Norman period pottery were more frequent. Late medieval and modern pottery was clearly dominant in all the trenches.

Trench 3-6 revealed the remains of a limekiln (Fig. 12), and in trench 2 (verification of 1991 survey), the walls of a water tank used for the preparation of lime. 


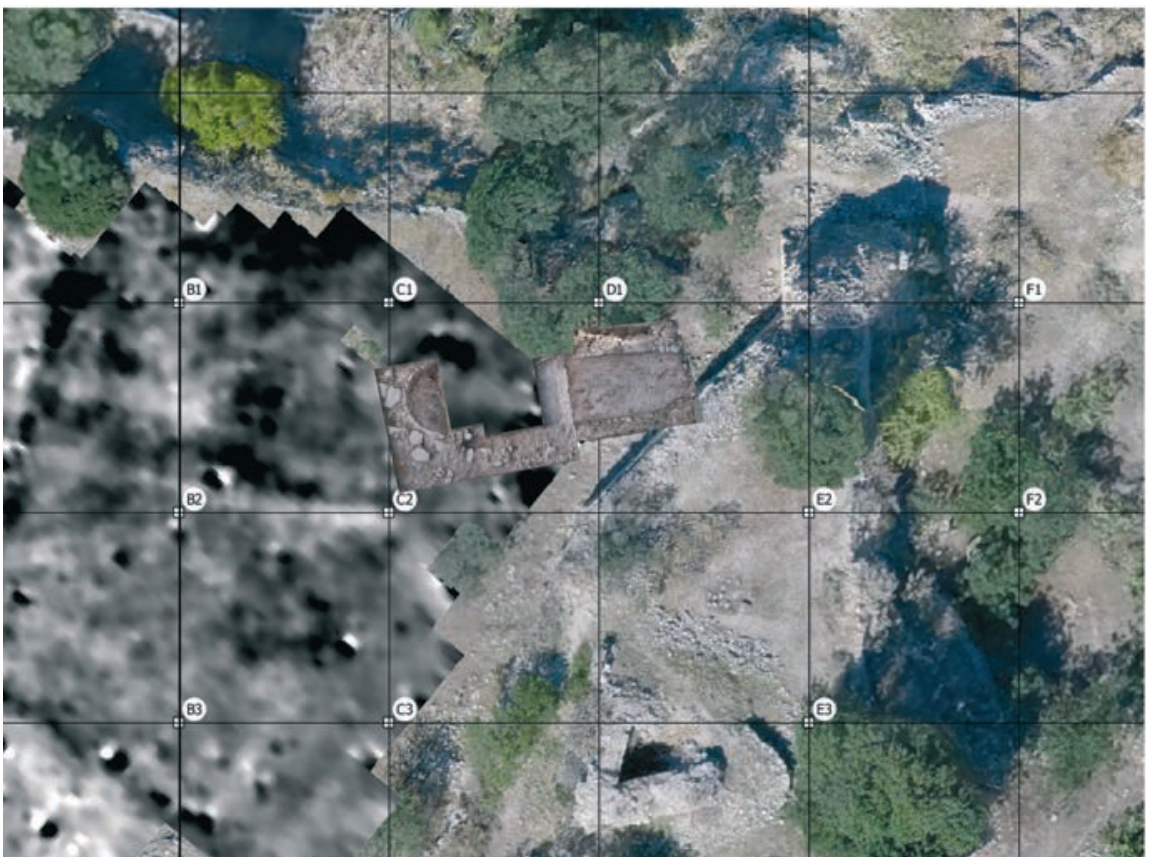

Fig. 9. Castello dei Tre Cantoni. Location of the building workshop in relation to the walls of the main section of the castle (excavations 2-6) (edited by K. Chrzan)

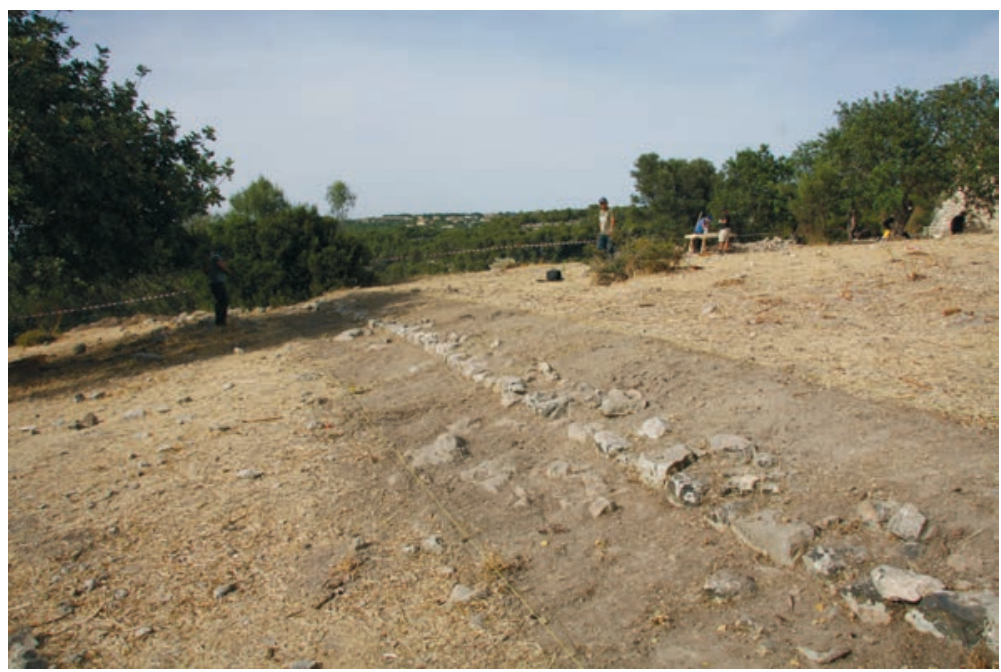

Fig. 10. Castello dei Tre Cantoni. View of trench 1 from the southern side after the beginning of the exploration (photo by S. Moździoch) 
Limekilns of similar construction were used in the area from ancient to modern times. This was facilitated, as mentioned above, by the presence of limestone rocks in the southern part of Sicily. In the immediate area of the town of Scicli, the remains of dozens of such kilns of different chronologies have been documented (Russino et al. 2008).

The kiln was used many times, probably still during the renovation of the walls in the $17^{\text {th }}$ century. This fact is also confirmed by single fragments of vessels from that period discovered in the kiln backfill. However, the origins of the object's use may date to the $14^{\text {th }}$ century, as indicated by ${ }^{14} \mathrm{C}$ dates from samples recovered from its bottom parts.

The lowest layers of the object (US 5-7) contained mainly fragments of pottery from the $14^{\text {th }}-15^{\text {th }}$ centuries and older. In trench 3 , mainly in the backfill of the kiln, 1178 fragments of pottery, 207 animal bones, four metal objects and one fragment of glass were discovered. Numerous fragments of roof tiles were also found, which were probably also fired in this kiln.

Due to the numerous levellings of the site as a result of rebuilding and perhaps hygienic practices, the cultural layers uncovered in the excavations reveal artefacts from the different eras in which San Matteo hill was used and possibly inhabited. The oldest of the pottery fragments found are from the Bronze Age. These are the so-called ceramica castelucciana (circa 2300-1700 BC), and ceramica Licodia Eubea (650-450 BC). Few fragments of pottery can be dated to the Greco-Hellenistic period, the Roman period, and the early Middle Ages (Byzantine and Arab periods $-6^{\text {th }}-11^{\text {th }}$ centuries). Numerous ceramic fragments come from the Norman and Suevian periods $\left(11^{\text {th }}-13^{\text {th }}\right.$ centuries $)$, with many more from the late Middle Ages $\left(14^{\text {th }}-16^{\text {th }}\right.$ centuries $)$ and the modern period $\left(16^{\text {th }}-18^{\text {th }}\right.$ centuries).

The state of archaeological research on the Sicilian Middle Ages seems still too little advanced to be able to more precisely date the stratigraphic units discovered using formal-typological analysis of the ceramics ${ }^{4}$. The best, although also imperfect, dating tool, therefore, remains the methods of natural sciences, such as radiocarbon dating, dendrochronology (difficult to apply in Sicily due to the scarcity of wooden relics), or, increasingly, thermoluminescence. Since the ${ }^{14} \mathrm{C}$ dates from the bottom parts of the kiln point in these two periods to the $2^{\text {nd }}$ half of the $14^{\text {th }}$ century, a major rebuilding of the castle walls likely took place at this time. In the second half of the $14^{\text {th }}$ century, Sicilian castles were characterised by relatively poor defences and outdated building techniques, reflecting the development of society and economy, which after a period of prosperity during the Norman dynasty began to lag behind other Western European countries.

\footnotetext{
${ }^{4}$ Most of the known studies of the ceramics concern mainly the Byzantine and Islamic (Arab) periods, i.e. the period from the $6^{\text {th }}$ to the $11^{\text {th }}$ century Molinari $1995 ; 1997 ; 2010 b$; Arcifa, Lesnes 1997; Ardizzone 1999; Mangiaracina 2012; 2013.
} 
Fig. 11. Castello dei Tre Cantoni. Trench 1: fragment of lucerne from the Arab period (edited by E. Moździoch)
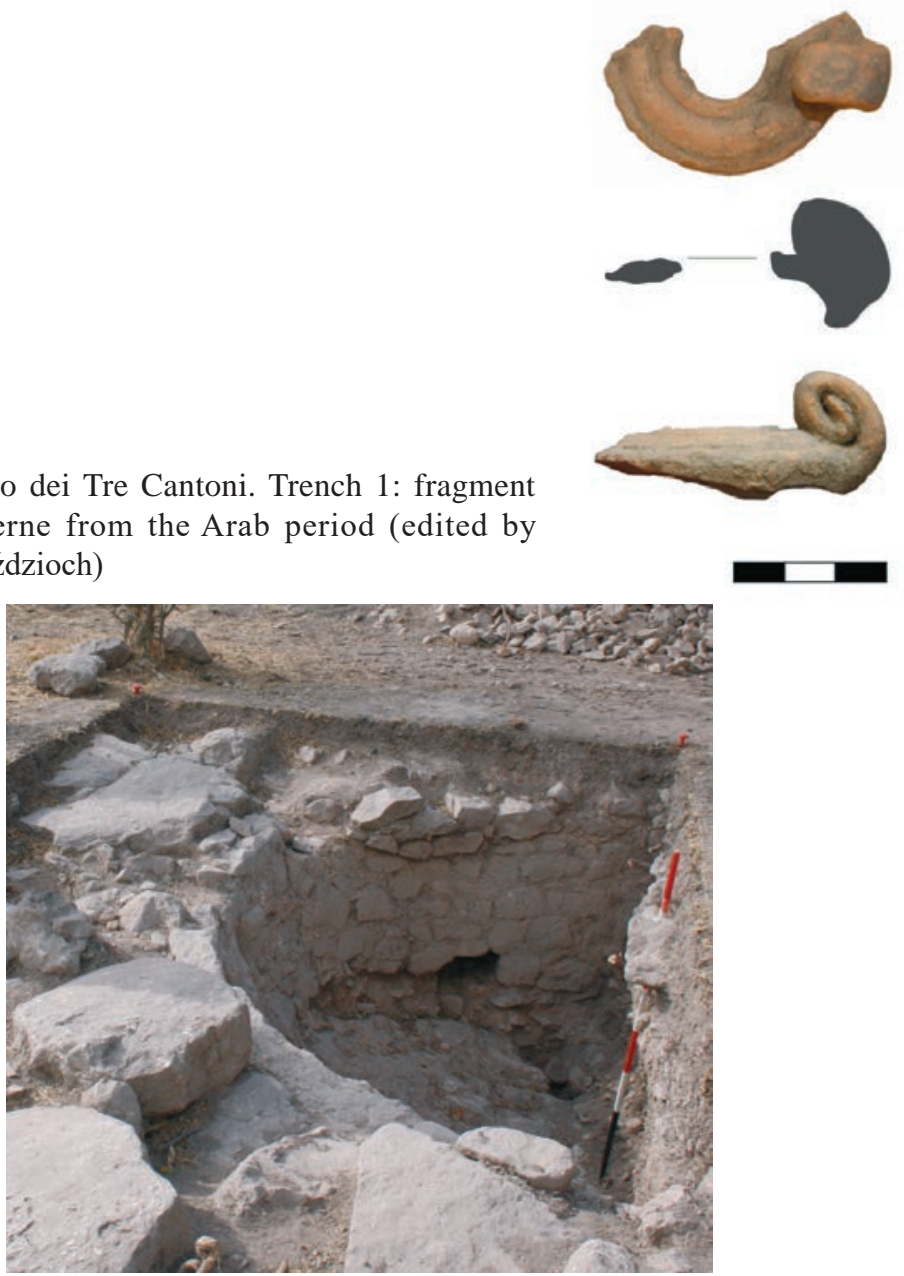

Fig. 12. Limekilns backfill during exploration. Visible level of layers from $14^{\text {th }}-15^{\text {th }}$ century (photo by S. Moździoch)

Perhaps the reconstruction of the walls at that time related to the fact that firearms were slowly becoming more widespread at the end of the $14^{\text {th }}$ century. We know that bombards used during sieges are mentioned in castle inventories as early as the early $15^{\text {th }}$ century.

All three mortar samples taken from the castle wall indicated the $2^{\text {nd }}$ half of the $14^{\text {th }}$ century to the $1^{\text {st }}$ half of the $15^{\text {th }}$ as the time of its construction (Figs. 13, 14). During this period, the castle wall was probably reinforced along a considerable length.

The research carried out in 2018 produced the first information, documented by systematic excavations, on the chronology of the fortification on the hill of San 


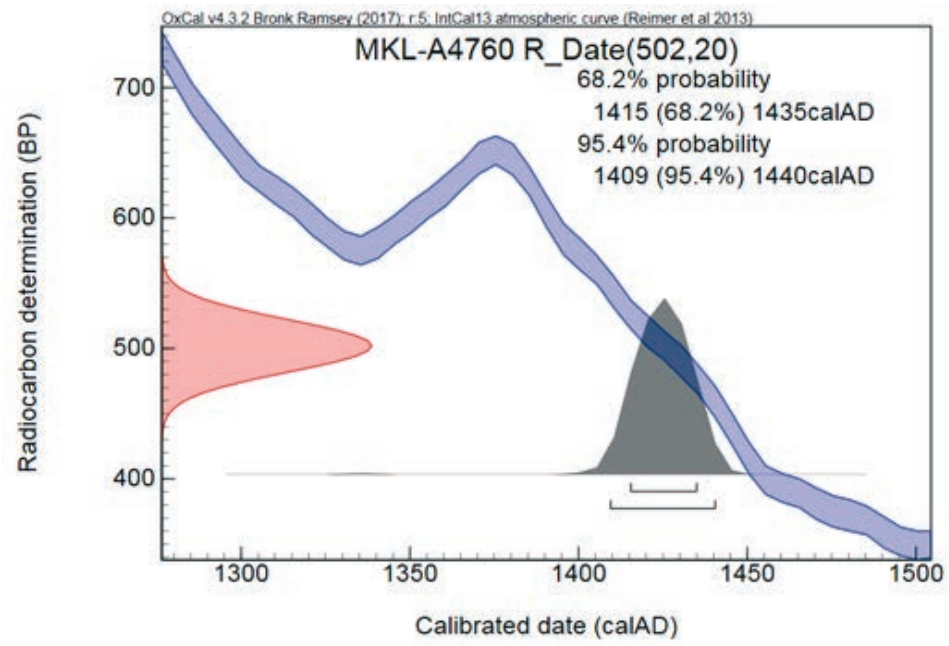

Fig. 13. Dating of one of the charcoal samples from the mortar taken from the face of the western wall of the castle (edited by M. Krąpiec)

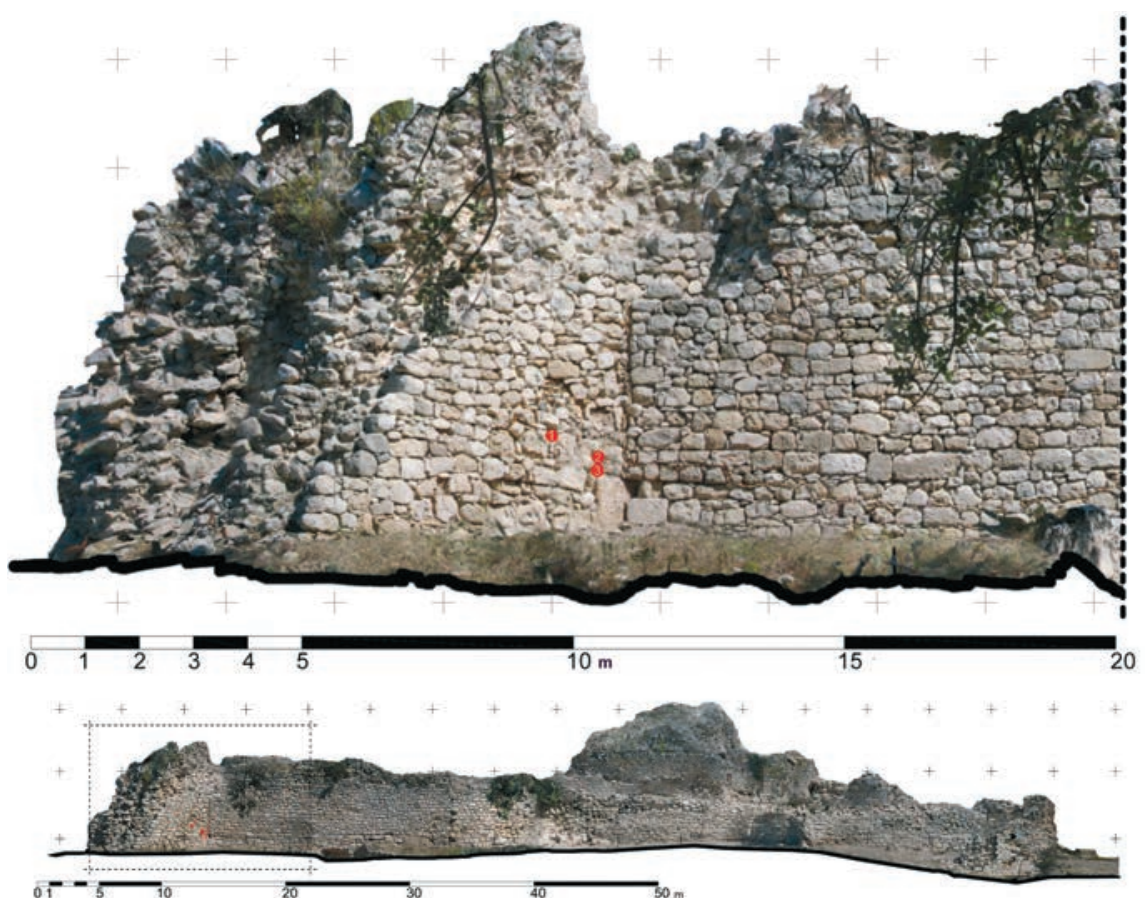

Fig. 14. Location of mortar samples taken from the western wall of the castle (photo by A. Kubicka) 
Matteo. Thanks to them, it was possible to discover a building workshop dating from the second half of the $14^{\text {th }}$ to the first half of the $15^{\text {th }}$ century and to confirm the castle wall's construction (reconstruction?) at the same time. Both the stratigraphy and the ${ }^{14} \mathrm{C}$ dates were obtained to confirm the castle's functioning from the $2^{\text {nd }}$ half of the $14^{\text {th }}$ century.

It has not yet been possible to document the existence of earlier phases of the castle walls archaeologically, although the above-mentioned finds of pottery from the Byzantine, Arab and Norman periods allow such a possibility.

Translated by Stawomir Moździoch

\section{References}

Arcifa L., 2000, Per una geografia amministrativa dell'altomedioevo in Sicilia. Nuove ipotesi di ricerca per un sito 'bizantino', [in:] Cittadella di Vendicari (SR). II Congresso Nazionale di Archeologia Medievale, ed. G.P. Brogiolo, Firenze, pp. 234-241.

Arcifa L., Lesnes E., 1997, Primi dati sulle produzioni ceramiche palermitane dal X al XV secolo, [in:] La céramique médiévale en Méditerranée. Actes du VI Congrés Internationale sur la Céramique Médiévale en Méditerranée, Aix en Provence, pp. 405-418.

Arcifa L., Tomasello F., 2005, Dinamiche insediative tra Tardoantico e Altomedioevo in Sicilia. Il caso di Milocca, [in:] Paesaggi e insediamenti rurali in Italia meridionale fra Tardo antico e Altomedioevo. Atti del Primo Seminario sul Tardoantio e l'Altomedioevo in Italia Meridionale (Foggia 12-14 febbraio 2004), eds. G. Volpe, M. Turchiano, Bari, pp. 649-665.

Ardizzone F., 1999, Le anfore recuperate sopra le volte del palazzo della Zisa e la produzione di ceramica comune a Palermo tra la fine dell'XI ed il XII secolo, Mélanges de l'École française de Rome, Moyen Âge, 111-1, pp. 7-50.

Augenti A., Galetti P., 2018, L'incastellamento: storia e archeologia: 40 anni da Les structures di Pierre Toubert, Spoleto.

Baranowski T., Moździoch S, Stanisławski B., 2017, Rapporto preliminare della I campagna di scavi archeologici condotti nel sito della Chiesa di Santa Maria di Campogrosso (San Michele del Golfo) - Altavilla Milicia-PA, Notiziario Archeologico Soprintendenza Palermo, no. 19/2017, pp. 1-13.

Bresc H., 1976, L'habitat médiéval en Sicile (1100-1450), [in:] Atti del Colloquio Internazionale di Archeologia medievale, Palermo, pp. 186-197.

Bresc H., 1984, Terre e castelli: le fortificazioni della Sicilia araba e normanna, [in:] Castelli. Storia ed archeologia, Relazioni e comunicazioni al Convegno di Cuneo (6-8 dic. 1981), eds. R. Comba,A A. Settia, Torino, pp. 73-87.

Bresc H., 1994, L'incastellamento in Sicilia, [in:] I Normanni popolo d'Europa. MXXX-MCC, Catalogo della mostra, Venezia, pp. 217-220. 
Bresc H., Maurici F., 2009, I castelli demaniali della Sicilia (secoli XIII-XV), [in:] Castelli e fortezze nelle città italiane e nei centri minori italiani (secoli XIII-XV), Centro Internazionale di Ricerca sui Beni Culturali, eds. F. Panero, G. Pinto, Cherasco, pp. 271-317.

Cacciaguerra G., 2009, Dinamiche insediative in Sicilia tra V e X secolo: tre contesti a confronto nell'area megarese, [in:] V Congresso nazionale di Archeologia Medievale (Manfredonia-Foggia, 30 settembre-3 ottobre), eds. G. Volpe, P. Favia, Firenze, pp. 296-301.

Canzonieri E., 1997, Il Castello dei Tre Cantoni di Scicli (RG). E l'analisi stratigrafica delle strutture murarie, [in:] eds. G.Volpe, P. Favia, Notiziario storico di Scicli, 3, pp. 61-99.

Carioti A., 1994, Notizie storiche della città di Scicli, vol. 2: XVIII secolo, ed. M. Cataudella, Scicli.

Cataudella A., 1988, Scicli, storia e tradizioni, Modica.

Di Stefano G., 2003, L'abitato rupestre nella Sicilia sud orientale: l'esempio di Ispica, [in:] 3 Congresso Nazionale di Archeologia Medievale (Salerno, 2-5 ottobre), eds. P. Peduto, R. Fiorillo, Salerno, pp. 510-515.

Di Stefano G., 2008, L'attività della Soprintendenza di Ragusa nel territorio di Scicli, [in:] Scicli: archeologia e territorio, ed. P. Militello, Palermo, pp. 33-38.

Di Stefano G., Fiorilla S., 1997, Scicli (Ragusa): il Castello dei Tre Cantoni, [in:] I Congresso Nazionale di Archeologia Medievale, Pisa 29-31 maggio 1997, ed. S. Gelichi, Firenze, pp. 92-96.

Da Piazza M., 1980, Cronica, ed. Antonino Giuffrida, Palermo.

Fiorilla S., 2004, Insediamenti e territorio nella Sicilia centromeridionale. Primi dati, Mélanges de l'Ecole française de Rome. Moyen-Age, vol. 116, no. 1, pp. 79-107.

Fiorilla S., 2013, Gli insediamenti iblei fra tardo antico e medioevo attraverso i reperti archeologici, [in:] Archaeotur: gestione integrata e promozione dei siti archeologici a Ragusa e Malta: $i$ siti archeologici del periodo tardoantico, eds. S. Scerra, O. Bruno, A. Colosi, S. Sirugo, Palermo, pp. 146-154.

Giuffre M., 1980, Castelli e luoghi forti di Sicilia, XII-XVII secolo, Palermo.

Krąpiec M., Moździoch S., Moździoch E., 2020, Dating of remains of the medieval church Santa Maria di Campogrosso in Sicily in the light of multidisciplinary studies, Radiocarbon, vol. 62, issue 6, pp. 1625-1636.

Lesnes E., 1997, I castelli feudali trecenteschi della Sicilia occidentale ed il loro territorio, [in:] I Congresso Nazionale di Archeologia Medievale, Pisa 29-31 maggio 1997, ed. S. Gelichi, Firenze, pp. 109-115.

Mangiaracina C.F., 2012, Costruzione di un sistema GIS a base regionale per lo studio della ceramica medievale in Sicilia, Archeologia e calcolatori, 23, pp. 51-64.

Mangiaracina C.F., 2013, La ceramica invetriata nella Sicilia islamica e normanna (X-XII secolo), [w:] La luce del mondo. Maioliche Mediterranee nelle terre dell'Imperatore. Catalogo della mostra organizzata dal Museo della Ceramica di Montelupo (S. Miniato 2 marzo-9 maggio 2013), eds. M. Caroscio, F. Berti, Firenze, pp. 89-105.

Maurici F., 1992, Castelli medievali in Sicillia. Dai Bizantini ai Normanni, Palermo. 
Maurici F., 1998, Il vocabolario delle fortificazioni e dell'insediamento nella Sicilia 'aperta' dei normanni: diversità e ambiguità, [in:] 'Castra ipsa possunt et debent reparari'. Indagini conoscitive e metodologie di restauro delle strutture castellane normanno-sveve (Atti del Convegno Internazionale di Studio, Castello di Lagopesole, 16-19 ottobre 1997), ed. C. D. Fonseca, De Luca, pp. 25-39.

Militello P., 1989, L'oppidum triquetrum' di Scicli (Ragusa), Archivio Storico Messinese, vol. 53, pp. 5-47.

Militello P., 2008, La ricerca sul territorio tra Ottocento e Novecento, [in:] Scicli: archeologia e territorio, ed P. Militello, Palermo, pp. 21-32.

Molinari A., 1994, Il popolamento rurale in Sicilia tra V e XIII secolo: alcuni spunti di riflessione, [in:] La storia dell'Alto Medioevo italiano (VI-X secolo) alla luce dell'archeologia, Atti del Convegno Internazionale, Siena 2-6 dicembre 1992, eds. R. Francovich. G. Noyé Firenze, pp. 361-377.

Molinari A., 1995, La produzione e la circolazione delle ceramiche siciliane nei secoli XXIII, [in:] Actes du $5^{\mathrm{èm}}$ colloque sur la céramique mèdièvale en Mèditerranèe occidentale (Rabat 11-17 Novembre 1991), Rabat, pp. 191-204.

Molinari A., 1997, Momenti di cambiamento nelle produzioni ceramiche siciliane, [in:] La céramique médiévale en Méditerranée, Actes du VI Congrés Internationale sur la Céramique Médiévale en Méditerranée, Aix en Provence, pp. 375-382.

Molinari A., 2004, L'archeologia medievale in Sicilia: un bilancio degli ultimi vent'anni, [in:] Metodologia, insediamenti urbani e produzioni. Il contributo di Gabriella Maetzke e le attuali prostettive delle ricerche, Viterbo, pp. 383-418.

Molinari A., 2010a, Paesaggi rurali e formazioni sociali nella Sicilia islamica, normanna e sveva (secoli X-XIII), Archeologia Medievale, 37, pp. 229-245.

Molinari A., 2010b, La ceramica siciliana di X e XI secolo tra circolazione interregionale e mercato interno, [in:] Pensare - classificare: studi e ricerche sulla ceramica medievale per Graziella Berti Gelichi, Sauro, eds. M. Baldassarri, S. Gelichi, Firenze, pp. 159-170.

Monumenta, 1894, Monumenta Germaniae Historica, ed. G. Pertz, vol. 3, no. 411, Berlin, p. 370.

Moździoch S., 2002, Castrum munitissimum Bytom. Lokalny ośrodek władzy w państwie wczesnopiastowskim, Warszawa.

Moździoch S., 2004, The Castrum Munitissimum Bytom - a local power centre of the early Piast State, [in:] Polish lands at the turn of the first and the Second Millennia, ed. P. Urbańczyk, Warsaw, pp. 305-318.

Pensabene P., 2006, L'insediamento medievale: inquadramento storico, [in:] Iblatasah Placea Piazza. L'insediamento medievale sulla Villa del Casale nuovi e vecchi scavi. Mostra Archeologica (Piazza Armerina, 8 agosto 2006-31 gennaio 2007), Piazza Armerina, pp. 65-70.

Pensabene P., 2008, Trasformazioni, abbandoni e nuovi insediamenti nell'area della villa del casale, [in:] L'insediamento medievale sulla Villa del Casale di Piazza Armerina. Nuove acquisizioni sulla storia della Villa e risultati, degli scavi 2004-2005, eds. P. Pensabene, C. Bannanno, Galatina, pp. 13-66. 
Pesez J.M., 1984, Brucato. Histoire et archéologie d'un habitat médiéval en Sicile, vol. 2, Roma.

Pirri R., 1733, Sicilia sacra disquisitionibus et notitiis illustrata, vol. 1, ed. A. Mongitore, V.M. Amico, vol. 1, Palermo [dostęp: 2019.09.27].

Rizzo M.S., 2004, L'insediamento medievale nella Valle del Platani, Roma.

Russino G., Zaccaria R., Guglielmo C., Ini M.W., Carbone M., 2008, Le carcare: storia e funzioni, [in:] Quaderni di Esplorambiente, no. 1, Scicli.

Santagati, L., 2006, Viabilità e topografia della Sicilia antica, vol. 1, Palermo.

Santagati, L., 2012, Storia dei Bizantini di Sicilia, Caltanisetta.

Sipione E., 1968, Tre documenti trecenteschi, Archivio Storico della Sicilia Orientale, 54, pp. 222-230.

Solarino R., 1885, La Contea di Modica, Modica, reed. Ragusa 1982.

Vassallo S., Moździoch S., 2018, Maria di Campogrosso: centro spirituale ed economico dai tempi della conquista normanna, Incontri. La Sicilia e l'altrove, no. 24(7-8), pp. 29-36 
